\title{
K některým prvkům teorie finančního účetnictvï
}

\author{
Miloslav Janhuba*
}

Jsem přesvědčen o tom, že je nezbytné, aby vhodně aplikované poznatky teorie účetnictví vedly $\mathrm{k}$ tomu, že např. dotyčný pozná podle účtové osnovy, zda soustava účtů obsahuje účty proudové vedle stavových, anebo jen stavové účty; zda je výkaz výsledovka konstruován pro vyčíslení výsledku hospodaření metodou nákladů na obrat, nebo jinak. Nezbytná je pro aplikování teoretických zákonitostí nutnost značné skepse, zejména při posuzování výstižnosti dat, která účetnictví poskytuje uživatelům pro jejich rozhodování. Výstižnosti, poznamenané jak zkreslením chybou měřítka, tak zkreslením z časového posunu a rovněž zkreslením, jež vytvořilo nepřizpůsobení struktury a rozsahu dat relevanci při rozdílných rozhodovacích úlohách (sc. data poskytovaná finančním účetnictvím především v účetní závěrce).

\section{Vymezení obsahu teorie}

Teorie účetnictvi ${ }^{1}$ má za úkol pokud možno vyčerpávajícím způsobem pokrýt vědomostní fond účetnictví, systematicky ho popsat a pokusit se nalézt co nejvyšší míru vnitřních vazeb, které existují mezi elementy tohoto vědomostního fondu. Dnešní normativní teorie účetnictví však si klade do určité míry odlišné cíle: s pragmatismem sobě vlastním se snaží charakterizovat (vyhýbám se použití pojmu „definovat“) to př́ípustné, dobré a chvályhodné v účetní praxi. Normativní teorie se snaží v míře dosti významné věnovat rovněž „nadstavbám základních pilírơu“, za které ovšem bývají z větší části (je otázka, zda z dlouhodobé perspektivy ku prospěchu věci) vydávány co možná obsáhlé konkrétní aplikace předpisů a směrnic pro provozování praktické účetní služby v platné národní úpravě pro podniky, př́padně pro instituce.

Problémem nadmíru významným ve všech těchto souvislostech je správné a jednoznačné pochopení obsahu pojmu „teoretický“ vúčetnictví. Vesměs se zcela pragmaticky (a nesprávně) za 'teoretické' považuje výčet tvrzení na základě platných normativních texti̊ (zákonů aj. předpisư) a uplatňovaných konvencí, neboli všechno to, co má „,kvalifikovaná odborná účetní síla“ vědět, znát a jedině používat při svých účtovacích činnostech. Lze se však ztotožnit s takto chápaným ,teoretickým“ v účetnictví? Vždyt' touto - jistě v dobré víře uplatněnou - volbou redukujeme onen svébytný, neobyčejně košatý a ve svém celku jistě exaktně neuchopitelný ,strom účetního poznání“ na přesně zastřižený, prořezaný a postřikem proti škůdcům ošetřený stromek v sadu zdatného ovocnáře!

Ono „teoretické“ v účetnictví má naplňovat výrok mudrce raného středověku, že „,vědou není jen popis toho, co jest, ale - a to zejména - toho, co by mohlo být, dokonce i toho, co je nedovoleno a zatracováno“. Teorie v účetnictví je fondem znalostí, přístupů a hodnocení, postupů a metod, které tu byly a jsou, úvah a doporučení k tomu, co bude.

\# Článek je zpracován jako jeden z výstupů výzkumného záměru Rozvoj účetní a finanční teorie a jeji aplikace v praxi z interdisciplinárního hlediska s registračním číslem MSM6138439903.

* Prof. Ing. Miloslav Janhuba, CSc. - profesor; Katedra finančního účetnictví, Fakulta financí a účetnictví, Vysoká škola ekonomická v Praze, nám. W. Churchilla 4, 13067 Praha 3; <mjanhuba@vse.cz>.

1 V celém dalším textu mám pod označením ,teorie účetnictví “ na mysli teorii té oblasti účetnictví, která se tradičně a ne stoprocentně výstižně označuje jako „finanční účetnictví. Někteří autoři mně již dříve vytkli, že generalizuji tam, kde by měly být odlišeny ,teorie finančního účetnictví a a teorie manažerského účetnictví‘ 


\section{Problematika kategorií}

Základní účetní kategorie a jejich pojmenování představují jednu ze stěžejních částí účetní teorie. V každém národním prostředí má teorie za nezbytný úkol pěstovat, udržovat a rozhojňovat pojmový aparát tak, aby ústrojně navazoval na dř́ive dosažený stav. Např. kategorie ,aktiva‘, ,pasiva‘, ,náklady‘, ,výnosy', ,zisk‘, dále pojmenování stran účtu Má dáti a Dal, abychom uvedli jen prŕíklady, jsou povýtce účetními kategoriemi a pojmenováními, ačkoliv je používají i jiné ekonomické disciplíny. Pochopitelně dnešní účetnictví se nemůže omezit jen na základní strukturotvorné kategorie a tak jak se rozšiřuje okruh jeho uživatelů a vynořují se nové souvislosti, musí se i jeho pojmový aparát stále přizpůsobovat novým požadavkům. Silné vlivy má zejména informační technologie, které se používá při jeho zpracování. Nebude na škodu připomenout si stručně obsah a strukturu především ,Soustavy pojmů (conceptual framework) IAS/IFRS a zamyslet se nad úplností charakteristik, pokud jde o jednotlivé složky této soustavy - a to především v souvislostech nejzásadnějších, tj. týkajících se validity při zachování podstaty podniku.

Koncepční rámec IAS/IFRS si klade za cíl vytvoření předpokladů pro pojmové sjednocení výrazů, podstatných pro vyjádření předmětu účetnictví a obsah či vypovídací schopnost závěrky; dále určit charakteristiky pro účetní započtení ${ }^{3}$ uvedených kategorií.

Podle Koncepčního rámce IAS/IFRS je cílem účetní závěrky poskytovat informace o výkonnosti ${ }^{4}$ firmy, o její finanční situaci a jejích změnách v uzavíraném roce všem uživatelům, pro jejichž ekonomická rozhodnutí jsou takové informace relevantní. Samozřejmostí v Koncepčním rámci IAS/IFRS je předpoklad, že předmětný podnik bude svoji činnost bez přerušení vykonávat i v dalších obdobích (going concern) a základnou pro započtení př́slušných veličin jako pozic výkazů účetní závěrky je předpoklad vzájemného dorůstání uskutečněných transakcí a jim př́slušných peněžních proudů v čase (accrual basis). ${ }^{5}$

Finančně-majetková situace podniku je prezentována $v$ prvé řadě obsahem rozvahy majetkové (bilance). Koncepční rámec IAS/IFRS se snaží v maximální míře precizovat základní složky bilance, jimiž jsou v jeho interpretaci aktiva a dluhy (závazky); vývažek ${ }^{6}$ představuje samostatnou složku, označovanou obvykle jako vlastní kapitál.

Aktiva jsou charakterizována jako podnikem získané a v plném rozsahu kontrolované prostředky ${ }^{7}$ na základě výsledků minulých událostí, od nichž se očekává př́liv užitků do podniku v budoucnu. Přitom se předpokládá, že budoucí př́liv užitku je dostatečně pravděpodobný a také, že př́íslušný prostředek je možno ,spolehlivě‘ocenit.

Dluhy jsou nynějším závazkem (povinností), jakožto výsledek minulých událostí, na základě jehož splnění lze s vysokou pravděpodobností očekávat odliv užitků z podniku

\footnotetext{
2 Jako ,předmět účetnictví se v normativních textech včetně českého zákona o účetnictví rozumí výhradně předmět praktického účtování (ratiocinium), nikoliv předmět účetní nauky (apologistica).

3 V angl. ,recognition'.

4 V angl., performance“

5 V češtině bych považoval za vhodné označení tohoto př́stupu k zobrazování veličin za ,spojitý‘ způsob, nebot' matematicky posuzováno můžeme při uplatnění tohoto způsobu vykázat výsledek za časový interval teoreticky nekonečně malý, což při ,pokladničním', tedy ,nespojitém', pagatorním způsobu (cash basis) není možné.

6 Často označováno jako reziduální veličina; termínem ,vývažek' překládám angl. ,balance‘, tedy veličina, jež vznikla jako rozdíl jistých hodnot a umistuje se k nižší z nich pro vyrovnání. Nelze zcela ztotožňovat se ,zůstatek ${ }^{6}$

7 V českém oficiálním překladu ,resources“ - ,prostředky, zásoby“, ne zcela vhodně přeloženo jako „zdroje“.
} 
v budoucnosti. Přitom splnění (vypořádání) dluhu může znamenat bud' platbu penězi, nebo převod jiných než peněžních aktiv, nebo poskytnutí služeb, nebo výměnu daného dluhu za jiný druh závazku, popř́ípadě transformaci dluhu na vlastní kapitál. Mezi dluhy lze počítat rovněž nepravé rezervy. ${ }^{8}$

Vlastní kapitál považuje K. R. IAS/IFRS za reziduální, zbytkovou veličinu, tvořenou rozdílem mezi aktivy a dluhy tak, aby rozvaha byla v rovnováze. Toto pojetí vlastního kapitálu (aniž se dotýkáme možnosti jeho podrobnější klasifikace) odpovídá v plném rozsahu té bilančně-teoretické bázi účetnictví, kterou je obvyklé označovat jako podnikatelské vlastnické pojeti ${ }^{9}$, a která chápe vlastníka jako oprávněného nakládat se ziskem a jako nedílnou součást podnikatelské jednotky, na rozdíl od jiné bilančně-teoretické báze, označované jako pojetí svébytnosti firmy.

\section{Bilance, účty a jejich soustavy}

Zcela zásadní částí teorie účetnictví je nauka o bilancích, účtech a jejich soustavách. Jde o dnes již ustálený soubor poznatků, který zejména v základní teorii účtů je dokončen a rozvíjí se dál v oblasti soustav účtů a především v oblasti bilančně-teoretické. Dřívější pojetí bilančních teorií soustřed'uje svoji pozornost na rozvahu majetkovou, moderní př́spěvky bilančních teorií se zaměřují rovněž na další účetní výkazy. Tzv. klasické bilanční teorie se především vyrovnávají s problematikou získávání informací pro uchování majetkové podstaty podniku (substance) v podmínkách hyperinflačního vývoje (Německo ve 20. letech 20. století). Pozitivní bilanční teorie amerického střihu si všímají již výhradně „přípustných“ vzorů výkazů a snaží se o normativní vymezení „dobré praxe“. Tento směr ústí v současné době ve zcela specificky zaměřenou teoretickou práci: tzv. „normativní teorii účetnictvi“". Bere si za cíl konzistentně budovat soustavu pravidel, která budou bezprostředně aplikována v praxi vykazování finančně-majetkové struktury podniku (rozvaha + výkaz o peněžních tocích) a výkonnosti jeho managementu (výsledovka + výkaz o změnách ve vlastním kapitále). Nikoliv tedy mapovat celou šířku již vyzkoušených možností a cest zobrazování syntetických veličin hospodaření prríslušné podnikatelské nebo nepodnikatelské jednotky (entity), ale sestavit maximálně jednoznačný „kuchařský předpis“ pro tvorbu a prezentaci výkazů dané entity. Není nic lepšího pro každodenní praxi a pro rozhodovací úlohy (včetně kontrolních rozhodovacích úloh spojených s auditorskou praxí).

\section{Uchování podnikové podstaty}

Závěrečná část textu Koncepčního rámce IAS/IFRS tvoří pravidla spojená s bilančněteoreticky koncipovanými př́ístupy k podnikové podstatě a jejímu uchování. I když koncepční rámec IAS/IFRS konstatuje, že u ve velké většiny firem a jejich výkazů je podniková podstata pojata finančně, připouští v zásadě i věcné (produkční nebo výkonové) pojetí podstaty a spojuje konkrétní přístup s uplatněnými požadavky uživatelů účetních výkazů.

\footnotetext{
8 Bilančně-teoreticky lze jako pravou rezervu vykázat pouze založený rezervní fond: část vlastního kapitálu, tvořená nerozděleným ziskem po zdanění (jeho částí), která je v aktivech v odpovídající výši založena zvláštní, vyčleněnou pozicí peněžní nebo peněžních ekvivalentů. Nepravé rezervy se dělí na dlužené a vlastní: vlastní nepravou rezervu jsme zvyklí obvykle označovat jako ,rezervní fond', dlužené nepravé rezervy jsme zvyklí označovat jako, ,rezervy“ a mohou je tvořit rezervy nákladové (v ČR např. rezerva na opravy dlouhodobých aktiv) nebo rezervy závazkové (přípustné podle Koncepčního rámce IAS/IFRS a představované např. nejistým závazkem z neukončeného soudního sporu, případně nejistým závazkem ze záruk kvality vlastních výkonů).

9 Angl. ,proprietary concept'.
} 
Lze říci, že koncepční rámec IAS/IFRS v závěrečných článcích pro potřeby široké praxe adaptoval (a zčásti účelově zjednodušil) rozsáhlou a pro všechny skupiny uživatelů účetních výkazů významnou problematiku uchování podnikové podstaty.

Aby mohla být tato - snad nejvýznamnější - složka informačního potenciálu výkazů účetní závěrky pochopena $\mathrm{v}$ plné šíri svého dosud stále teoreticky diskutovaného obsahu, poukažme na možnosti, které pro vykázání podstaty podniku účetní závěrka může využít, které historicky prakticky využila a jaká problematika je spojena se zajišt'ováním informací pro uchování podstaty podniku.

NOMINÁLNÍ UCHOVÁNÍ: počet peněžních jednotek měny vykazování reprezentující vlastní kapitál v rozvaze na počátku období je roven nebo je nižší, než počet peněžních jednotek reprezentující vlastní kapitál v rozvaze na konci období.

UCHOVÁNÍ KUPNí SíLY: počet jednotek stálé kupní síly reprezentující vlastní kapitál v rozvaze na konci období je roven nebo je vyšší, než počet jednotek téže kupní síly reprezentující vlastní kapitál v rozvaze na počátku období.

REPRODUKČNÍ UCHOVÁNÍ substance (a): čistá aktiva ${ }^{10} \mathrm{v}$ nynějších cenách na konci roku jsou vcelku ohodnocena stejnou nebo vyšší částkou jako čistá aktiva ve srovnatelných cenách na počátku roku.

KVALIFIKOVANÉ UCHOVÁNÍ substance (b): čistá aktiva v nynějších cenách na konci roku jsou vcelku ohodnocena částkou, která je vyšší než částka čistých aktiv ve srovnatelných cenách na počátku roku alespoň o obnos představující průměrný růst v celém hospodářství, přepočtený na podmínky daného podniku.

BRUTTO PŘÍSTUP ad a), nebo ad b): vylučují se všechny zdánlivé zisky.

NETTO PŘíSTUP ad a), nebo ad b): vylučují se zdánlivé zisky u aktiv financovaných z vlastního kapitálu, zdánlivé zisky u ostatních aktiv se považují za neutralizované současnými zdánlivými ztrátami spojenými s financováním z cizího kapitálu.

Zachování podnikové podstaty nemusí být nutně zjišt'ováno na základě údajů ve výkazech účetní závěrky, tzv. teorie ekonomického zisku vychází ze zjišt'ování výnosové hodnoty podniku a jejího porovnávání v různých obdobích. Podobnou cestou jdou novější bilančněteoretické názorové školy, označované jako ,kapitálové teorie očekávaného vývoje ${ }^{11}$.

Zatímco Koncepční rámec IAS/IFRS v podstatě připouští uplatnění každého účetního modelu, který vyústí ve výkazy informující o zajištění podnikové podstaty ve finančním nebo ve věcném pojetí (včetně zajištění reprodukčního a kvalifikovaného), nacházíme v USA některé modifikace uvedených prŕstupů. $\mathrm{V}$ americké účetní teorii závisí formulace cílů účetnictví, zpředmětněných v účetní závěrce, na řešení konfliktu zájmů, který objektivně existuje na trhu informací. Speciálně, výkazy účetní závěrky jsou výsledkem interakcí tří skupin: firem, uživatelů a účetních pracovníků. Firmy zahrnují největší složku, která se

\footnotetext{
${ }^{10}$ Čistá aktiva jsou bilančně-teoreticky vymezena jako objem a struktura podnikových aktiv financovaných $\mathrm{z}$ vlastních zdrojů. Pouze výjimečně lze v praxi zjistit strukturu čistých aktiv, zatímco jejich objem je roven vlastnímu kapitálu. V celém následujícím textu se ,vlastním kapitálem` chápe veličina odvozovaná na straně pasiv rozvahy, na rozdíl od ,čistých aktiv`, jimiž se chápe veličina odvozovaná na straně aktiv rozvahy, zejména na základě tzv. ,přiřazovací fíkcíc‘.

11 Takto např. prof. Dr. Gerhard Seicht ve své ,Bilanztheorien` (1982).
} 
v účetním procesu angažuje. Jejich provozními, finančními a mimořádnými (tj. neprovozními) aktivitami je odůvodněna existence účetních výkazů. Existence a chování firem má za následek vytváření finančních výsledků, které jsou zčásti vyčíslitelné v procesu zpracování účetnictví. Firmy tedy tvoří potenciál pro účetní informace. Uživatelé vytvářejí druhou skupinu. Produkce účetních údajů je ovlivněna jejich zájmy a potřebami. Není ovšem možné sestavit kompletní seznam všech uživatelských skupin, takový seznam by měl zahrnovat vlastníky, finanční analytiky, věřitele a vládní organizace. Účetní pracovníci vytvářejí třetí skupinu, která přichází do styku s informacemi, obsaženými ve výkazech účetní závěrky. Účtaři zpravidla působí jako ,auditoři“" v tíži odpovědnosti prokázat, že výkazy jsou v souladu s obecně uznávanými účetními zásadami.

Jsou-li uvedené konflikty zájmů brány jako fakt, můžeme uvést tři možné přístupy k formulování cílů účetnictví.

První prístup posuzuje soubor informací, které je firma ochotna zveřejnit a pokouší se najít nejlepší prostředek pro jejich vyčíslení a ověření.

Druhý prístup se soustřed'uje na informace, které je schopna účetní profese vyčíslit a ověřit a pokouší se vyhovět uživatelům i firmám různými účetními možnostmi.

Třetí př́istup hledí na soubor informací považovaný uživateli za relevantní jako na nejdůležitější a přesvědčuje účetní a firmy, aby produkovali a ověřovali právě takové informace.

Zjednodušeně shrnuto, první přístup je orientován ,firemně‘, druhý př́stup je orientován ,profesně‘ a třetí ,uživatelsky“. Pochopitelně při nadřazenosti politických a legislativních vazeb bude převažovat uživatelský př́stup, pokud jsou formulovány budoucí cíle výkazů. Ve skutečnosti platí v USA a ve Velké Británii uživatelský přístup, zatímco oba další př́istupy zůstávají ve směrnici č. 4 . Výboru pro účetní zásady USA. Tento výbor doporučil, aby byly definovány cíle účetnictví a aby základní pojetí, principy a terminologie, známé jako „obecně prỉíimané účetní zásady“, byly očíslovány a popsány.

Podle US-GAAP jsou cíli účetního výkaznictví: produkce informací potřebných pro ekonomická rozhodnutí vnějších uživatelů výkazů; v nich zejména produkce srozumitelných údajů pro predikci budoucích peněžních toků, v neposlední řadě o objemu a struktuře aktiv podniku, o nárocích (vlastních, cizích) na tato aktiva a o jejich změnách v uplynulém období. Cílů se dosahuje především dodržováním srozumitelnosti, relevantnosti při rozhodování jak s ohledem na budoucnost, tak také při hodnocení minulého vývoje, ověřitelnosti, neutrality, srovnatelnosti a konzistentnosti při požadavku řádného zobrazení skutečnosti. Výkazy mají být sestaveny a podrobně strukturovány při dosažení užitku přesahujícího pořizovací výlohy jednotlivých údajů, jen z významných položek a s respektováním opatrnosti jejich vykázání. Za základní položky výkazů účetní závěrky se v US-GAAP považují v rozvaze aktiva, dluhy a vlastní kapitál, ve výsledovce výnosy a $\mathrm{k}$ nim uplatněné náklady, ve výkazu o změnách vlastního kapitálu kapitálové vklady a výběry vlastníků a ostatní změny ekvity včetně újmy (loss) a př́nosu (gain) dávající tzv. úplný zisk.

Výše uvedená pojetí zachování podnikové podstaty, at’ jsou formulována teoretiky kontinentální Evropy, nebo teoretiky americkými, představují jistou úroveň historicky již dlouhého zápasu mezi peněžně-nominálním a peněžně-věcným obsahem hlavních účetních výkazů. 
Historicky vzato je účetnictví (a tudíž i výkazy na něj navazující) schopno podat relativně spolehlivý a přesný obraz o stavu a pohybu nominálních peněžních jednotek užitých ve směnných transakcích, které se $\mathrm{v}$ dané jednotce ve vykazovaném časovém intervalu opravdu uskutečnily. Toto peněžně-nominální zobrazení vychází $\mathrm{z}$ historie účetnictví a účetního výkaznictví. Veškeré záznamy na počátku existence moderního účetnictví byly záznamy o pohybu peněz u obchodníka se zbožím: penězi se transakce začínaly a jimi řetěz transakcí také končil a bylo možno jednoznačně určit, jakého bylo dosaženo výsledku (na transakci vydal méně peněz než kolik jich přijal = zisk, v opačném př́padě ztráta). Nebylo příliš problematické zahrnout do takových záznamů termínované obchody a př́slušným způsobem započítat úrok. Teprve sílící a zákonně prosazované požadavky na vykazování celkové situace a dosažených výsledků jednotlivých firem $\mathrm{k}$ určitému datu dávají vzniknout fenoménu, který jsme zvyklí označovat jako růstová (spojitá, akruální) základna zobrazování, tj. účtují se (a vykazují) nejen skutečné proudy peněžních výdajů a peněžních příjmů, ale také potenciální proudy nárokovaných plateb penězi (náklad) a nárokovaných př́ijmů peněz (výnos) proto, aby mohl být k určitému datu vyčíslen odhadovaný výsledek z nároků vedle dosaženého výsledku ze skutečných proudů peněz.

Každý ryze nominální př́stup k obsahu účetních záznamů a výkazů účetní závěrky musí nutně vést ke konstatování, že nemůžeme dobře (správně) vyčíslit výsledek, který není dosud přeměněn ve skutečnou diferenci mezi (definitivním) př́jmem peněz a odpovídajícími (definitivními) peněžními výdaji. To je možné až v okamžiku faktického ukončení všech podnikových aktivit při jeho likvidaci, v tzv. totálním výsledku.

Každý ryze věcný přístup k obsahu účetních záznamů a výkazů účetní závěrky musí vyvolat $\mathrm{v}$ život snad prakticky neuskutečnitelné plynulé přehodnocování peněžního obrazu všech složek podnikových aktiv, dluhů a vlastního kapitálu podle okamžité situace na trhu.

Převaha prvků jednoho nebo druhého př́stupu spolu s potřebou vyrovnat se s ošemetným faktem kolísání kupní síly peněžní jednotky vedla nakonec ke vzniku řady názorových ,škol‘, označovaných jako ,bilanční teorie', z nichž každá přispěla svou trochou k procesu řešení problémů, které jsou spojeny s tím faktem, že v zásadě přijímáme jako „kvalitnějšíi“ postup, jímž je totální výsledek zpětně rozkládán do jednotlivých období vykazování podle uskutečněného prodeje výkonů (růstová, spojitá báze), a nikoliv podle objektivně uskutečněných př́ijmů a výdajů peněz (pagatorní, nespojitá báze).

\section{Ryze nominalistický př́stup}

Reprezentantem ryze peněžně-nominálního př́stupu k vymezování obsahu položek bilančních aktiv a pasiv je v teoretické literatuře prof. Wilhelm Rieger $(1878-1971)$. Jeho dodnes v plné šíri nepochopená - teoretická koncepce vychází z neměnnosti peněžní jednotky jako měřítka hospodářských jevů a jejich důsledků na podnikovou ekonomiku. Svoje učení vypracoval jako reakci na jiné, v té době aktuální bilančně-teoretické přístupy, zejména na organickou bilanci prof. Fritze Schmidta (1929).

Pro Riegerův (1928) nominalistický př́istup je základem pro všechny účetní údaje (tedy i pro veličiny vykazované v rozvaze) výhradně uskutečnění peněžních př́ijmů a peněžních výdajů. To znamená, že obsahem aktivních rozvahových položek nejsou jednotlivé věcné statky, př́padně ocenitelná práva, ale výhradně a pouze peněžní prostředky + uskutečněné peněžní výdaje; obsahem pasivních rozvahových položek pak nejsou jednotlivé zdroje financování věcných statků a ocenitelných práv, ale výhradně a pouze peněžní př́ijmy, které plynuly od vlastníků a věřitelů. Přitom z tohoto chápání obsahu bilančních aktiv a pasiv 
pochopitelně plynou některá obsahová úskalí: Rieger se musel vypořádat s existencí závazků a pohledávek, které jsou teprve očekávanými peněžními výdaji či prŕijmy. Jeho řešení tohoto problému je svým způsobem zvláštní, avšak přijatelné za předpokladu, že máme k dispozici úplnou informaci o konečném peněžním osudu daného závazku nebo dané pohledávky. Rieger totiž požaduje provést svého druhu lineární přepočet případné diference mezi nominální výší závazku či pohledávky a její definitivní peněžní podobou v čase existence př́slušného vztahu a vykázat ho v rozvaze částkou, která po tomto přepočtu připadá na rozvahový den. To je možné bez problémů provést např. u pevně úročených vztahů; tam, kde se podle našich informací nominální a skutečně placená (přijatá) částka nebude lišit, je přepočet zbytečný. Žádný jiný způsob transformace veličin bilančních aktiv nebo pasiv v nominalistické Riegerově koncepci rozvahy není prŕípustný, zejména ne jakýkoliv přepočet plynoucí ze změny cen nebo cenové hladiny (inflace).

\section{Ryze materialistický (věcný) př́stup}

Reprezentantem ryze peněžně-věcného přístupu k vymezování obsahu položek bilančních aktiv a pasiv je v teoretické literatuře prof. Fritz Schmidt (1877 - 1962). Jeho názor na obsah bilančních pozic se od Riegerova liší především v tom, že potřeboval zachovat věcnou podstatu podniku (substanci), nikoliv nominálně vyjádřené objemy peněžních jednotek přijatých a investovaných. Základem pro zajištění informací o vývoji substance je pro Schmidta stálý přehled o statcích a závazcích v jejich dnešních cenách. Dnešní cenou mu byla jednoznačně cena na nabývacím trhu. Aby vyhověl potřebám vykazovat věcně stabilní, avšak cenově rozkolísané podnikové poměry, zavedl do svojí organické bilance několik zvláštních položek (např. fond ze změny cen odpočívajícího majetku - u Schmidta mohl být vykazován jako pasivní nebo jako aktivní položka podle cenového vývoje), zejména pak ale položku významně přispívající k informování uživatelů o „pravém“ vývoji situace ve výsledku hospodaření. Přepočty nominálních aktiv (pohledávky, peněžní prostředky) a nominálních pasiv (dluhy) u Schmidta vedou k vykázání samostatné veličiny ,zdánlivý zisk/ztráta z inflace“" na rozdíl od „pravého“ (organického) zisku, který si firma zasloužila obratem.

\section{Oceňování}

Vyčíslování hodnoty prvků účetních výkazů jako snad nejvýznamnější transformace, kterou účetnictví podstupuje při započítávání aktiv, pasiv, výnosů a nákladů ve výkazech, věnuje Koncepční rámec IAS/IFRS celkem tři články. Po vymezení vlastního procesu vyčíslování ${ }^{12}$ jsou přehledně popsány právě čtyři základny, které tvoří bázi pro vlastní proces číselného hodnotového vyjádření jednotlivých prvků výkazů, tedy pro jejich ocenění. Koncepční rámec IAS/IFRS připouští samostatnou existenci nebo kombinaci těchto modelů (základen): ceny skutečně použité (historické), ceny nynějších (hypotetických) pořizovacích operací, nynější (hypoteticky) dosažitelné peněžní částky (při prodeji aktiv, nebo vypořádání dluhů), a konečně současné (diskontované) hodnoty očekávaných peněžních toků. Přednost se v praxi dosud stále dává cenám skutečným (historickým), kombinovaným př́padně s prvky dalších modelů při běžném uplatnění zásady obezřetnosti. Jestliže u skutečných cen máme $\mathrm{k}$ dispozici vyčíslení opravdu (true) trhem objektivizovanými částkami peněz, které však od okamžiku uskutečnění záznamu nepřetržitě stárnou, jsou dvě další oceňovací základny konstruovány na hypotéze koupě a prodeje, uskutečněné za ideálních podmínek.

\footnotetext{
${ }^{12}$ Angl. ,measurement' $v$ těchto souvislostech nelze přeložit jako ,měření', dokonce nelze bezprostředně použit pojmu ,oceňování‘; domnívám se, že obsahově je nejlépe celý proces vystižen označením ,vyčíslování'.
} 
I když se nejedná ani vzdáleně o skutečné (tj. reálné ${ }^{13}$ ) události, ocenění s využitím těchto základen má nespornou výhodu v pružné reakci takové základny na aktuální vývoj na trhu. Jejich použití je do značné míry podmíněno metodickým vyjasněním způsobu promítnutí rozdílů mezi stávajícím účetním oceněním a oceněním hypotetickou hodnotou ( $\mathrm{tj}$. ve výsledku, anebo mimo výsledek daného období). Oceňovací základna ,diskontované peněžní toky‘ je sice teoreticky nejvhodnější, avšak její praktické použití (mimo zcela přesně vymezené situace) zatím bude stále narážet na nejednotná východiska. Variantnost oceňovacích základen (modelů) pro vyjádření peněžního rozměru položek účetních výkazů je jedním ze základních znaků vytváření konkrétních bilančně-teoretických názorových škol (viz výše).

\section{Vývoj účetních forem}

Tato část teorie je její nejstabilnější složkou. Zabývá se deskripcí a jistým uspořádáním účetní praxe v lidských dějinách podle poznaných a všeobecně přijímaných kritérií. Časový horizont zde sahá od nejstarších civilizačních zpráv až k dnešku. Historická zkoumání v této oblasti jsou velmi užitečným pramenem poznání nejen již dosažené úrovně, ale také všech (pokud možno) „nepovedeností““ a „omylů“, které byly v hlavním vývojovém proudu opuštěny a nahrazeny lépe se osvědčivšími postupy. Rozsah a hloubka těchto zkoumání stále vzrůstá, tak jak pokračují samy lidské dějiny a tak přibývají studijní prameny. Lze konstatovat, že oblast účetní historie reprezentuje dnes naprosto svébytnou a relativně oddělenou složku teorie účetnictví, která se v řadě př́ípadů prezentuje vysoce obecně ceněnými poznatky a závěry pro historii vůbec a pro hospodářské dějiny speciálně. Vývoj účetnictví nejlépe dokumentuje nauka o účetních formách, tedy o způsobech, jimiž bylo účetnictví provozováno podle stupně rozvoje ekonomických vztahů a technického pokroku. Dnes se spíš nostalgicky pousmějeme nad variantností účetních forem druhé poloviny devatenáctého a první poloviny dvacátého století, kdy se trh doslova „hemžil“" nabídkami technických prostředků pro usnadnění účetních prací a postupem času prostředků jejich mechanizace (účetní rámy, účtovací mř́žǩky, účtovací stroje). Existující formy zpětně ovlivňovaly jak chápání významnosti všech uskutečňovaných zápisů, tak také stabilizaci kontrolních prvků, které jsou dodnes nedílnou součástí účetních prací (inventarizace a její složky, kontroly formálních vazeb mezi dílčími oblastmi účetních zápisů, např. v deníku a v hlavní knize atp.). Úplný přehled všech účetních forem je dnes obtížné podat, vzhledem $\mathrm{k}$ existenci dílčích odchylek např. $\mathrm{v}$ jednotlivých národních regionech. Pro naše současné poznání mají význam jednotlivé vývojové etapy:

1. elementární účtování (nesystematické zápisy především dluhů [povinností] a práv),

2. pokladní účtování (peněžní př́ijmy a výdaje členěné podle účelu),

3. obchodní účtování ve dvou knihách (adversáŕ (makulář) a pokladní deník),

4. italské účetnictví (popsané L. Paciolim v Traktátu o účtech a zápiscích 1494 - český překlad viz Janhuba, 2005),

5. účetnictví s více deníky (přepisovací anglická, francouzská a německá forma),

6. účetnictví s více okruhy (původně tzv. ,zřejmé‘ a ,tajné‘ účetnictví obchodníka),

\footnotetext{
${ }^{13}$ Neustále je nutno zdůrazňovat obsahovou nesmyslnost v češtině cizopasného termínu „reálná hodnota“!
} 
7. propisovací účetnictví a strojové účetnictví (mechanizované),

8. účetnictví s počítačovou podporou,

9. účetnictví v počítači s virtuálními knihami.

Pro dokumentaci některých účetních forem a jejich existenci i v českých zemích nacházíme i archivní prameny (napřs. purkrabské účty panství Novohradského dokumentují existenci 2. etapy vývoje účetních forem v zemích Koruny české. Srov. Janhuba (2004). Soudobá historická zkoumání doplňují mozaiku našeho poznání vývoje účetnictví o dílčí cenné poznatky, $\mathrm{z}$ nichž lze $\mathrm{v}$ některých př́padech odvodit i význam (původní obsah) některých dodnes běžných rozvahových položek, př́kladem mohou být třeba 'Oprávky k dlouhodobým aktivům.

\section{Závěr}

Základní stavební kameny teorie účetnictví mají co do obsahu pochopitelně samy vlastní historický vývoj. Ještě před dvěma desetiletími bylo samozřejmou součástí teorie účetnictví Mezinárodní srovnávací účetnictví, které se intenzivně zabývalo popisem rozdílů v přístupu jednotlivých národních úprav $\mathrm{k}$ obsahu konkrétních účetních operací. Dnešní situace rozvinutého sjednocování zejména účetních výkazů (harmonizace postupně vedoucí ke standardizaci výstupů) tuto část teorie odsunula na nevýznamnou kolej. Lze se nadít, že to bude v některých souvislostech osudem i dalších složek teorie účetnictví.

\section{Literatura:}

[1] Janhuba, M. (2005): Základy teorie účetnictví. Praha, Oeconomica, 2005.

[2] Janhuba, M. (2004): Accounting in Bohemia a Century Before Pacioli. In: Mejzlík, L. (ed.): Programme and Collected Abstracts - 27th Annual Congress of the EAA. Praha, VŠE, 2004, s. 120-121.

[3] Pacioli, L.: Summa de arithmetica, geometria, proportii et proportionalita, dist. IX., Tract XI. particularis, de computis et scripturis. Venetia, Paganino Paganini, 1494.

[4] Rieger, W.: Einführung in die Privatwirtschaftslehre. Nürnberg, Bahre, 1928.

[5] Seicht, G.: Bilanztheorien. Würzburg/Wien, Physica-Verlag, 1982

[6] Schmidt, F.: Organische Tageswertbilanz. Leipzig, G. A. Gloeckner, 1929. 


\title{
K některým prvkům teorie účetnictví
}

\author{
Miloslav Janhuba
}

\begin{abstract}
ABSTRAKT
Př́spěvek se zabývá podrobnější charakteristikou některých základních prvků teorie účetnictví (účetní vědy). Zdůrazňuje nezbytnost pochopení základních pojmů, kategorií i výstavby teorie účetnictví pro další rozvoj procesu standardizace účetního výkaznictví. Popisuje hlavní etapy vývoje účetnictví tak, jak se historicky objevily, spolu s jejich základními poznávacími znaky.
\end{abstract}

Klíčová slova: Finanční účetnictví; Teorie účetnictví; Aktiva; Pasiva; Náklady; Výnosy; Koncepční rámec standardizace; Oceňování; Bilance; Účty.

\section{Some Components of Accounting Theory}

\begin{abstract}
This paper focused on detailed characterization of some basic elements of accounting science. The author highlighted the necessity of understanding basic terms, categories and constitution of accounting theory for next development of the standardization process by financial reporting. The cardinal phases of accounting history and basic recognition attributes of theirs are described.
\end{abstract}

Key words: Financial accounting; Accounting theory; Assets; Expenses; Revenue; Conceptual framework of IAS/IFRS; Evaluation; Balance sheet; Accounts.

JEL classification: M41 